\title{
Severity of Alternaria Leaf Spot of Brinjal caused by Alternaria alternata in Kashmir, India
}

\author{
Zakir Khursheed Raina*, Roaf Ahmad Rather, Showkat Ahmad Bhat, \\ T.A. Wani, N.A. Bhat and Stanzin Dorjey
}

Division of Plant Pathology, Faculty of Agriculture, Sher-e-Kashmir University of Agricultural Sciences and Technology, Wadura Sopore, 191121 Jammu and Kashmir, India

*Corresponding author

\section{A B S T R A C T}

\section{Keywords}

Alternaria alternata, Brinjal, Kashmir, Leaf spot, Survey

Article Info

Accepted: 04 April 2018 Available Online: 10 May 2018
Alternaria leaf spot caused by Alternaria alternata is one of the important foliar diseases of brinjal (Solanum melongena L.) The present study on severity of Alternaria leaf spot of brinjal in Kashmir valley was conducted during kharif 2016. An extensive survey was conducted in three districts of Kashmir valley viz., Anantnag, Baramulla, and Budgam revealed that disease was prevalent in all the three districts with mean disease incidence and intensity of 30.76 and 9.77 per cent, respectively. The maximum disease incidence of 38.68 and intensity of 14.07 per cent was observed in district Budgam and minimum disease incidence of 21.73 and intensity of 5.88 per cent was observed in district Anantnag.

\section{Introduction}

Brinjal (Solanum melongena L.) or egg-plant belonging to family Solanaceae, is believed to have originated from India (Zeven and Zhukovsky, 1975) and many species of this plant still grow as wild in this country. Brinjal is also a popular vegetable in China, Japan, Egypt, Italy, USA, Syria, Philippines, Thailand, Indonesia, France, and Turkey (Beura et al., 2008). In India, it is grown throughout the country round the year except in Jammu and Kashmir State where it is only a Kharif season crop. The total area under brinjal cultivation in the world is 1864.32 thousand hectares with annual production and productivity of 49782.16 thousand Metric Tonnes and 26.70 MT per hectare respectively (Anonymous, 2015a). In India it is cultivated over an area of 711.30 thousand hectares with an annual production of 13557.81 thousand MT and productivity of 19.1 MT per hectare wherein, Jammu and Kashmir covered the cultivated area of 2.02 thousand hectares with an annual production of 45.24 thousand MT and productivity of 22.39 tonnes per hectare (Anonymous, 2015b). Egg plants are a very good source of protein and dietary fiber. The fruits are also rich in potassium, manganese, copper, vitamin B1, vitamin B6, foliate, magnesium, and niacin (Aykroyd, 1963). Brinjal crop is attacked by number of fungal, 
bacterial, viral and phytoplasmal diseases like Alternaria leaf spot (Alternaria alternata (Fr.) Keissler), Damping off (Pythium aphanidermatum (Eds.) fitz.; Phytophthora spp.; Rhizoctonia spp.), Phomopsis blight (Phomopsis vexans Sacc. and Syd.) Harter, Cercospora leaf spot (Cercosporasolani melongenae Chupp. C. solani.), Verticillium wilt (Verticillium dahliae Kleb), Fusarium wilt (Fusarium solani (Mart.) App and Wollenw), Bacterial wilt (Ralstonia solanacearum Smith), Little leaf (Phytoplasma.), Mosaic virus, Root-knot nematodes (Meloidogyne javanica (Treub) Chitwood) during various growth stages which reduce its yield and quality of fruits. The Genus Alternaria Nees. Ex Fr. belongs to the sub-division Deuteromycotina, class Hyphomycetes, family Dematiaceae (Woudenberg et al., 2013).

The genus is widely distributed all over the world. The fungus grows and sporulates on plant debris during periods of rain, heavy dew, or under good moisture conditions. This disease is severe and appears regularly, causing heavy losses in yield. Balai and Ahir (2013) reported upto 25\% yield losses from Jaipur district due to leaf spot of brinjal. The disease first makes its appearance in young seedling. It attacks leaves and then spreads to fruits which subsequently rot and become unfit for consumption (Bochalya et al., 2012). Initially disease appears as small, dark brown and sunken spots, which subsequently gets converted into concentric rings and then become olivaceous dark brown lesion due to spore formation.

\section{Materials and Methods}

The present investigations on the status of Alternaria leaf spot of brinjal was undertaken in three districts located from north to the south of Kashmir valley at 1580 meters to 2000 meters (amsl) were surveyed to assess the disease incidence and intensity. The details of materials and methodologies followed during the course of investigation are described here under:

\section{Survey for disease status}

Field survey of commercially important vegetable growing belts in the districts of Anantnag, Budgam and Baramulla was carried out during the month July - August 2016. Each district was represented by three locations and each location by three sites. Mean of three fields represented disease incidence and intensity of respective site. Nine plants each at four corners and centre of the fields were randomly selected and their leaves were examined for recording disease incidence and disease intensity.

Per cent disease incidence and intensity was calculated by using the following formula:

Per cent disease incidence was calculated as per the formula:

Per cent disease incidence $=\frac{\text { Number of infected leaves }}{\text { Total Number of leaves examined }} \times 100$

The disease intensity was recorded using 0-5 scale (Pandey and Pandey, 2001) with slight modifications. Six categories were made on the basis of per cent leaf involved (Plate 1) as per the following key:

Per cent disease intensity (PDI) was calculated as per the following formula:

Per cent disease intensity $=\frac{\sum(\mathrm{n} \times \mathrm{v})}{\mathrm{N} \times \mathrm{S}} \times 100$

Where,

$\sum=$ Summation

$\mathrm{n}=$ Number of diseased leaves in each category 
$v=$ Numerical value of the category

$\mathrm{N}=$ Total number of leaves examined, and

$\mathrm{S}=$ Maximum numerical rating

\section{Results and Discussion}

With a view to find out the status of Alternaria leaf spot of brinjal in Kashmir valley, the survey was carried out in three districts viz., Anantnag, Budgam, and Baramulla of Kashmir valley for the prevalence of Alternaria leaf spot of brinjal during kharif 2016. The data on disease incidence and intensity recorded are presented in Table 1 and 2.

\section{Disease incidence}

The data presented in Table 1 revealed that Alternaria leaf spot of brinjal was prevalent in all the sites of districts surveyed with varying levels of incidence ranging from 17.82 per cent to 45.86 per cent. The highest disease incidence was recorded in district Budgam (38.68\%) followed by district Baramulla
(31.89\%) while as the district Anantnag $(21.37 \%)$ exhibited the least disease incidence. The disease incidence ranged from 17.82 to 25.78 per cent in district Anantnag, whereas in Baramulla from 29.42 to 37.64 per cent and in Budgam it ranged from 33.86 to 45.86 per cent. Among the locations surveyed highest disease incidence of 43.21 per cent was recorded in chadoora followed by Khansahib $(36.76 \%)$, lowest disease incidence was recorded in Shahbad (20.70\%). On an overall comparison amongst different sites surveyed, the highest disease incidence of 45.86 per cent was recorded in Qaisarmulla followed by Bugam (42.87\%) and Nowbugh (40.89\%). The least disease incidence of 17.82 per cent was recorded in Shangrin. Statistical analysis of the surveyed data revealed that the limits for average disease incidence fluctuated between 18.78 to 24.61 per cent for Anantnag district and 29.92 to 33.59 per cent for Baramulla district. Similarly, for Budgam district the limits fluctuated between 36.55 to 40.77 per cent respectively. However, the average statistical limits in all the three districts at all the locations in incidence fluctuated between 28.41 to 32.99 per cent.

Survey for disease status

\begin{tabular}{|c|c|c|c|c|}
\hline S. No. & $\begin{array}{l}\text { Name of } \\
\text { District }\end{array}$ & No. of Locations & $\begin{array}{l}\text { No. of sites per } \\
\text { location }\end{array}$ & Total sites \\
\hline 1. & Anantnag & 03 & 03 & 09 \\
\hline 2. & Baramulla & 03 & 03 & 09 \\
\hline 3. & Budgam & 03 & 03 & 09 \\
\hline Total & 03 & 09 & 09 & 27 \\
\hline
\end{tabular}

The disease intensity

\begin{tabular}{|l|c|c|}
\hline Category & Grade & Criteria (\% diseased leaf area covered) \\
\hline I. & 0 & No infection/ disease \\
\hline II. & 01 & $0.1-10.0$ \\
\hline III. & 02 & $10.1-25.0$ \\
\hline I V. & 03 & $25.1-50.0$ \\
\hline V. & 04 & $50.1-75.0$ \\
\hline VI. & 05 & $75.1-100$ \\
\hline
\end{tabular}


Table.1 Incidence of Alternaria leaf spot of brinjal in various locations of Kashmir valley during 2016

\begin{tabular}{|c|c|c|c|c|c|}
\hline \multirow[t]{2}{*}{ District } & \multirow[t]{2}{*}{ Location } & \multirow[t]{2}{*}{ Site } & \multirow[t]{2}{*}{$\begin{array}{l}\text { Per cent } \\
\text { Disease } \\
\text { Incidence }\end{array}$} & $95 \%$ & I. ***; \\
\hline & & & & Lower limit & Upper limit \\
\hline \multirow{12}{*}{ Anantnag } & \multirow[t]{4}{*}{ Achabal } & Haji Dantar & $25.78 *$ & \multirow{4}{*}{19.82} & \multirow{4}{*}{25.78} \\
\hline & & UttarsooNajigund & 20.83 & & \\
\hline & & Lalan & 21.83 & & \\
\hline & & Sub Mean & 22.83 & & \\
\hline & \multirow[t]{4}{*}{ Breng } & Sagam & 21.27 & \multirow{4}{*}{19.42} & \multirow{4}{*}{37.92} \\
\hline & & Larnoo & 19.98 & & \\
\hline & & HilarArhama & 23.72 & & \\
\hline & & Sub Mean & 21.66 & & \\
\hline & \multirow{4}{*}{ Shahbad } & Larkipora & 20.12 & \multirow{4}{*}{17.11} & \multirow{4}{*}{24.29} \\
\hline & & Shangrin & 17.82 & & \\
\hline & & Mehmooabad & 24.18 & & \\
\hline & & Sub Mean & 20.70 & & \\
\hline & \multicolumn{2}{|c|}{ Overall mean } & 21.73 & 18.78 & 24.61 \\
\hline \multirow{13}{*}{ Baramulla } & \multirow{4}{*}{ Sopore } & Arampora & 37.64 & \multirow{4}{*}{32.28} & \multirow{4}{*}{37.92} \\
\hline & & Chinkipora & 35.12 & & \\
\hline & & Wadura & 32.64 & & \\
\hline & & Sub Mean & 35.13 & & \\
\hline & \multirow{4}{*}{ Pattan } & Palhalan & 30.72 & \multirow{4}{*}{29.47} & \multirow{4}{*}{31.27} \\
\hline & & Wusan & 29.66 & & \\
\hline & & Nehalpora & 31.66 & & \\
\hline & & Sub Mean & 30.68 & & \\
\hline & \multirow{4}{*}{ Baramulla } & Stadiumcolony & 31.66 & \multirow{4}{*}{28.01} & \\
\hline & & Johama & 28.52 & & \\
\hline & & Chakla & 29.42 & & 38.52 \\
\hline & & Sub Mean & 29.87 & & \\
\hline & & all mean & 31.89 & 29.92 & 33.59 \\
\hline & & Kremshore & 37.54 & & \\
\hline & Khansahib & Khansahib & 36.89 & & \\
\hline & & Wager & 35.86 & 35.73 & 29.92 \\
\hline & & Sub Mean & 36.76 & & \\
\hline & & Bugam & 42.87 & & \\
\hline Budgam & Chadoora & Qaisarmulla & 45.86 & & \\
\hline & & Nowbugh & 40.89 & 40.26 & 46.14 \\
\hline & & Mean & 43.21 & & \\
\hline & & Kuthipora & 33.86 & & \\
\hline & Mazhama & Kawoosa & 36.31 & & \\
\hline & & Dawlatpora & 38.09 & 33.66 & 38.52 \\
\hline & & Sub Mean & 36.09 & & \\
\hline & & all mean & 38.68 & 36.55 & 40.77 \\
\hline & erall disease & dence & 30.76 & 28.41 & 32.99 \\
\hline
\end{tabular}

*Average of three fields at each site.

$* *$ C.I. $=$ Confidence Interval 
Table.2 Intensity of Alternaria leaf spot of brinjal in various locations in the Kashmir valley during 2016

\begin{tabular}{|c|c|c|c|c|c|}
\hline \multirow[t]{2}{*}{ District } & \multirow[t]{2}{*}{ Location } & \multirow[t]{2}{*}{ Site } & \multirow{2}{*}{$\begin{array}{c}\text { Disease } \\
\text { Intensity (\%) }\end{array}$} & \multicolumn{2}{|c|}{ 95\% C.I. $* * *$} \\
\hline & & & & Lower limit & Upper limit \\
\hline \multirow{12}{*}{ Anantnag } & \multirow{4}{*}{ Anantnag } & Haji Dantar & $6.40^{*}$ & \multirow{4}{*}{5.57} & \multirow{4}{*}{7.03} \\
\hline & & UttarsooNajigund & 5.60 & & \\
\hline & & Lalan & 6.92 & & \\
\hline & & Sub Mean & 6.31 & & \\
\hline & \multirow{4}{*}{ Breng } & Sagam & 5.62 & \multirow{4}{*}{4.91} & \multirow{4}{*}{6.49} \\
\hline & & Larnoo & 5.13 & & \\
\hline & & HilarArhama & 6.53 & & \\
\hline & & Sub Mean & 5.76 & & \\
\hline & \multirow{4}{*}{ Shahbad } & Larkipora & 6.13 & \multirow[b]{4}{*}{4.91} & \multirow[b]{4}{*}{6.08} \\
\hline & & Shangrin & 5.05 & & \\
\hline & & Mehmooabad & 5.57 & & \\
\hline & & Sub Mean & 5.58 & & \\
\hline & \multicolumn{2}{|c|}{ Overall mean } & 5.88 & 5.13 & 6.53 \\
\hline \multirow{12}{*}{ Baramulla } & \multirow{4}{*}{ Sopore } & Arampora & 12.19 & \multirow{4}{*}{9.86} & \multirow{4}{*}{12.13} \\
\hline & & Chinkipora & 10.13 & & \\
\hline & & Wadura & 10.73 & & \\
\hline & & Sub Mean & 11.01 & & \\
\hline & \multirow{4}{*}{ Pattan } & Palhalan & 9.41 & \multirow[b]{4}{*}{8.08} & \multirow[b]{4}{*}{10.57} \\
\hline & & Wusan & 10.32 & & \\
\hline & & Nehalpora & 8.15 & & \\
\hline & & Sub Mean & 9.29 & & \\
\hline & \multirow{4}{*}{ Baramulla } & Stadiumcolony & 8.99 & \multirow[b]{4}{*}{6.68} & \\
\hline & & Johama & 7.01 & & \\
\hline & & Chakla & 7.42 & & \\
\hline & & Sub Mean & 7.81 & & 8.92 \\
\hline & & 11 mean & 9.37 & 8.20 & 10.54 \\
\hline & & Kremshore & 14.18 & & \\
\hline Budgam & & Khansahib & 12.17 & & \\
\hline & Khansahib & Wager & 11.82 & & \\
\hline & & Sub Mean & 12.72 & 11.29 & 8.20 \\
\hline & & Bugam & 15.86 & & \\
\hline & & Qaisarmulla & 16.82 & & \\
\hline & Chadoora & Nowbugh & 14.69 & & \\
\hline & & Sub Mean & 15.79 & 14.52 & 16.86 \\
\hline & & Kuthipora & 13.32 & & \\
\hline & & Kawoosa & 14.13 & & \\
\hline & Mazhama & Dawlatpora & 13.82 & & \\
\hline & & Sub Mean & 13.70 & 13.41 & 14.20 \\
\hline & & ll mean & 14.07 & 12.72 & 14.42 \\
\hline & Ill disease in & & 9.77 & 8.80 & 10.70 \\
\hline
\end{tabular}

*Average of three fields at each site.

$* *$ C.I. $=$ Confidence Interval 


\section{Disease intensity}

The data presented in Table 2 revealed that Alternaria leaf spot of brinjal was prevalent in all the sites of districts surveyed with varying levels of intensity ranging from 5.05 per cent to 16.82 per cent. The highest disease intensity was recorded in district Budgam $(14.07 \%)$ followed by district Baramulla (9.37\%) while as the district Anantnag (5.58\%) exhibited the least disease incidence. The disease intensity ranged from 5.05 to 6.92 per cent in district Anantnag, whereas in Baramulla from 7.01 to 12.19 per cent and in Budgam it ranged from 11.82 to 16.82 per cent. Among the locations surveyed highest disease intensity of 15.79 per cent was recorded in Chadoora followed by Khansahib $(12.72 \%)$, lowest disease intensity of 5.58 per cent was recorded in Shahbad. On an overall comparison amongst different sites surveyed, the highest disease intensity of 16.82per cent was recorded in Qaisarmulla followed by Bugam (15.86\%) and Nowbugh (14.69\%). The least disease intensity of 5.05 per cent was recorded in Shangrin. Statistical analysis of the surveyed data revealed that the limits for average disease intensity fluctuated between 5.13 to 6.53 per cent for Anantnag district and 8.20 to 10.54 per cent for Baramulla district. Similarly, for Budgam district the limits fluctuated between 12.72 to 15.42 per cent respectively. However, the average statistical limits in all the three districts at all the locations in intensity fluctuated between 8.80 to 10.70 per cent.

Brinjal (Solanum melongena L.) is a major solanaceous vegetable crop of India after tomato and potato. Plant diseases are greatest constraints in commercial crop cultivation and always upset our calculations of crop production and crop protection. Evidently, our most component of Indian vegetarian dietbrinjal or egg-plant cultivation also faces serious economic threat due to various diseases. Among all Alternaria leaf spot caused by Alternaria alternata (Fr.) Keissler is an important foliar disease observed in severe form since last few years. Establishing the disease status is pre-requisite to decide the adoption of management strategies. In the present study, survey conducted in three districts of Kashmir valley during kharif 2016 indicated that Alternaria leaf spot of brinjal was more or less prevalent in all the locations of the districts. The average disease incidence was highest (38.68\%) in district Budgam followed by district Baramulla (31.89\%) and Anantnag $(21.73 \%)$. The disease incidence at various locations revealed that maximum disease incidence was recorded at Chadoora (43.21\%) followed by Khansahib (36.76\%) while lowest disease incidence was recorded in Shahbad (20.70\%). Among the different sites surveyed highest disease incidence was recorded at Qaisarmulla (45.86 \%) followed by Bugam (42.87\%) and Nowbugh (40.89\%) areas of district Budgam, while as the lowest disease incidence was recorded at Shangrin $(17.82 \%)$ site of district Anantnag. Results about the disease intensity revealed that district Budgam (14.07\%) was having highest disease intensity followed by Baramulla (9.37\%) while as lowest disease intensity was recorded in Aanantnag (5.88\%). On comparing different locations it was observed that highest disease intensity was found in Chadoora $(15.79 \%)$ while as lowest intensity was observed in Shahbad (5.59\%). Among the different sites surveyed highest disease intensity was recorded at Qaisarmulla (16.82\%) followed by Bugam (15.86\%) and Nowbugh (14. 69\%) areas of district Budgam, while as the lowest disease intensity was recorded at Shangrin $(5.05 \%)$ site of district Anantnag. The survey results are well supported with that of Balai and Ahir (2013), they observed 25.32 per cent intensity when surveyed on leaf spot disease of brinjal caused by Alternaria alternate in Jaipur district of Rajasthan. Premila (2014) recorded 9.5 to 
29.5 per cent incidence of leaf spot disease on brinjal in Manipur. Similar results about the prevalence of the disease have also been reported by Balai et al., (2010).

\section{References}

Anonymous, 2015a. Food and Agriculture Organisation Statistics. Food and Agriculture Organisation of United Nations, Rome, Italy. http://faostat.fao. org/default.aspx, pp. 567.

Anonymous, 2015b. Indian Horticulture Database. Ministry of Agriculture. Government of India, pp. 282-286.

Balai, L. and Ahir, R., 2013. Survey and Occurrence of Leaf Spot of Brinjal Caused by Alternaria alternata (Fr.) Keissler in Jaipur District. Advances in Life Sciences, 2(1):71-72

Balai, L., Ahir, R. and Yadav, S. 2010. Varietal screening of brinjal genotypes against leaf spot of disease caused by Alternaria alternata. Environment and Ecology 31: 1276-1278.

Beura, S. K., Mahanta, I. C. and Mohapatra, K. B. 2008. Economics and chemical control of Phomopsis twig blight and fruit rot of brinjal. Journal of Mycopathological Research 46:73-76.

Bochalya, S., Shkhawat, S., Singh, R. and Chohan, P.K. 2012.Studies on age of fruit, age of inoculum and inoculum load on development of Alternaria fruit rot of brinjal caused by Alternaria alternata. Annals of Agri BioResearch, 18: 388-390.

Pandey, A. and Pandey, B. 2001. Fungal diseases of brinjal in Bareilly region. Advances in Plant Sciences 14:99 - 104.

Premila, A., 2014. Leaf Spot Disease of Brinjal: Epidemiological Aspects and Traditional Management in Manipur. International Journal of Innovative Research and Development, 3(2).

Woudenberg, J., Groenewald, J., Binder, M., and Crous, P. 2013. Alternaria redefined. Studies in Mycology 75: 171212.

Zeven, A. and Zhukovsky, P. 1975. Dictionary of cultivated plants and their centers of diversity (p. 219). Wageningen: Center for Agricultural Publishing and Documentation.

\section{How to cite this article:}

Zakir Khursheed Raina, Roaf Ahmad Rather, Showkat Ahmad Bhat, T.A. Wani, N.A. Bhat and Stanzin Dorjey. 2018. Severity of Alternaria Leaf Spot of Brinjal caused by Alternaria alternata in Kashmir, India. Int.J.Curr.Microbiol.App.Sci. 7(05): 322-328. doi: https://doi.org/10.20546/ijcmas.2018.705.041 